\title{
Genel Kolluk Kuvveti Öğrencilerinin Organ Bağışı ve Nakli Hakkındaki Bilgi Düzeyleri* $^{*}$
}

\section{Knowledge Levels on Organ Donation and Transplantation among the General Law Enforcement Students}

Alper Tunga Kökcüi

iMD., PhD., Jandarma ve Sahil Güvenlik Akademisi, Birinci Basamak Muayene ve Aile Sağlığı Merkezi https://orcid.org/0000-0002-7517-3294

Öz

Amaç: Bu çalışmanın amacı bir yükseköğretim kurumundaki genel kolluk kuvveti öğrencilerinin organ bağışı ve nakli hakkındaki bilgi düzeylerini ölçmektir.

Yöntem: Kesitsel tanımlayıcı tipteki bu çalışma, Ankara'da bulunan bir yükseköğretim kurumunda 2-9 Aralık 2019 tarihleri arasında yürütülmüştür. Orantısal tabakalı basit tesadüfi örnekleme yöntemi ile seçilen 583 öğrenci çalışmanın örneklemini oluşturmaktadır. Verilerin toplanmasında 17 maddeden oluşan “Organ-Doku Bağışı ve Nakli Bilgi Ölçeği” kullanılmış olup, analizler istatistik yazılım paket programı kullanılarak yapılmıştır.

Bulgular: Büyük çoğunluğu erkek $(\% 91,4)$ ve bekâr $(\% 81,6)$ olan katılımcıların yaşları 18 ile 37 yıl arasında değişmekte olup, yaş ortalaması $25,32 \pm 4,13$ yıldır. Öğrencilerin ölçekte bulunan önermelere verdikleri cevapların puan ortalaması $12,73 \pm 2,49$ 'dur. Kadın öğrencilerin puan ortalamasının erkek öğrencilerinkinden yüksek olduğu görülmüştür $(p<0,05)$. Katılımcıların diğer tanımlayıcı özelliklerine göre ölçek puanı ortalamalarında anlamlı bir farklılık bulunamamıştır.

Sonuç: Katılımcıların bilgilerinin yeterli düzeylerde olmadığı görülmüş olup, öğrencilerin organ bağışı ve nakli hakkında özellikle düşük düzeyde farkındalık tespit edilen konularda bilgilendirilmeleri önerilmektedir. Organ bağışı ve nakli konusunda bilinçlendirilmiş öğrencilerin, mezuniyetleri sonrasında farklı bölgelerde görev yapacak olmaları dikkate alındığında; organ bağışına yönelik toplumsal farkındalığın arttırılmasına katkı sunabilecekleri düşünülmektedir.

Anahtar Kelimeler: Organ bağışı, Organ nakli, Farkındalık

\section{ABSTRACT}

Aim: The aim of this study is to assess knowledge levels on organ donation and transplantation among the general law enforcement students in a higher education institution.

Methods: This cross-sectional descriptive study was conducted at a higher education institution in Ankara between 2 and 9 December 2019. A total of 583 students who were selected by using proportional stratified simple sampling method formed the sample of study. "Organ-Tissue Donation and Transplantation Knowledge Scale" consisting of 17 items was used to collect the data, and the analysis was performed by using the statistical software package program.

Results: The mean age of participants most of whom were male (91.4\%) and unmarried (81.6\%) was $25.32 \pm 4.13$, and ranged from 18 to 37 years. The mean score of the students' responses to the statements in the scale was $12.73 \pm 2.49$. It was observed that the mean score of female students was higher than that of male students $(p<0.05)$. According to the other descriptive characteristics of the participants, no significant difference was found in the means of the scale scores.

Conclusion: It was observed that the knowledges of the participants were not at the sufficient levels, and it is recommended that the students be informed about the organ donation and transplantation, especially the issues with low awareness. Considering the fact that the students who are conscious about organ donation and transplantation will work in different regions after their graduation, it is thought that they can contribute to raising public awareness about organ donation.

Keywords: Organ donation, Organ transplantation, Awareness

*Lokman Hekim Dergisi, 2020; 10 (2): 162-170

DOI: $10.31020 /$ mutftd.663059

e-ISSN: $1309-8004$

Geliş Tarihi-Received: 22 Aralık 2019; Kabul Tarihi - Accepted: 24 Şubat 2020

iletişim - Correspondence Author: Alper Tunga Kökcü <alpertungakokcu@comu.edu.tr> 


\section{Giriş}

Organ nakli, günümüzde son dönem organ yetmezliği için en iyi ve sıklıkla tek hayat kurtarıcı tedavi olarak kabul edilen yerleşik bir tedavi şeklidir. ${ }^{1}$ Kişinin hayatta iken serbest iradesi ile ölümü sonrasında doku ve organlarının başka hastaların tedavisi için kullanılmasına izin vermesi ve bunu belgelendirmesi organ bağışı olarak tanımlanmaktadır. ${ }^{2}$

Dünyada ilk başarılı organ nakli 1954 yılında Amerika'da Joseph Murray tarafından alıcının tek yumurta ikizinden canlı donör olarak gerçekleştirilen böbrek naklidir. ${ }^{3}$ Richard Lillehei ve William Kelly tarafından 1966 yılında ilk pankreas nakli, 1967 yılında ise ilk ince bağırsak nakli yapılımıştır. ${ }^{4}$ ilk başarılı karaciğer nakli 1967 yılında Thomas Starzl tarafından yapılmış olup, ilk kalp nakli de Christiaan Barnard tarafından aynı yılın sonlarında gerçekleştirilmiştir. ${ }^{5,6}$ Türkiye'de 1968 yılında iki hastaya yapılan kalp nakilleri başarısızlıkla sonuçlanmış, ilk başarılı kalp nakli ise 1989 yılında Cevat Yakut ve Ömer Beyazıt tarafından gerçekleştirilmiştir.7 Mehmet Haberal tarafından 1975 yılında canlı donörden, 1978 yılında kadavra donörden ilk başarılı böbrek nakilleri ve 1988 yılında da kadavra donörden ilk başarılı karaciğer nakli yapılmıştır. ${ }^{8} 1989$ yılında ise Fahrettin Alparslan tarafından ilk pankreas nakli gerçekleştirilmiştir. ${ }^{9}$ ilk başarılı akciğer nakli 1983 yılında Kanada'da Toronto Akciğer Transplantasyonu Grubu tarafından, Türkiye'de ise 2009 yılında Süreyyapaşa Akciğer Transplantasyonu Çalışma Grubu tarafından gerçekleştirilmiştir. ${ }^{10,11} 20$. yüzyılın ikinci yarısı, hem dünyada hem de Türkiye'de organ nakillerinde ilklerin yaşandığı bir dönem olmuştur. Organ ve Doku Alınması, Saklanması, Aşılanması ve Nakli Hakkında Kanun 1979 yılında yürürlüğe konulmuştur. 2000'li yıllara gelindiğinde ise ilgili alt mevzuatlar da yayınlanarak organ ve doku nakli hizmetleri tamamen Sağlık Bakanlığının kontrol ve koordinasyonunda yürütülmeye başlanmıştır. Günümüzde, Türkiye'de solid organ nakillerinin yanı sıra doku ve kompozit doku nakilleri de yapılabilmektedir.

Tüm dünyada organ nakli talebi artmakta, ancak ihtiyacı karşılayacak yeterli organ bulunamamaktadır. Bağışlanan organ sayısının yetersizliği kronik organ yetmezliği olan birçok hastanın tedavisinde sınırlayıcı bir faktör olup, bekleme listelerinde çok sayıda hastanın birikmesine yol açmaktadır. ${ }^{12} 2018$ yılında, Türkiye'de organ nakli bekleme listelerinde kayıtlı olan 32983 hastanın 5599'una nakil yapılmış olmasına rağmen, 2559'u organ nakli beklerken hayatını kaybetmiş ve aynı yıl bekleme listelerine 9073 yeni hasta kaydedilmiştir. ${ }^{13}$ Ülkemizdeki organ nakli sayısı yüksek düzeylerde olsa da bekleme listelerindeki hasta sayısını karşılamaktan uzaktır. Bu durumun başııca nedeni kadavra donör sayılarındaki yetersizliktir. 2018 yılında, milyon kişi başına düşen kadavra donör sayısı kapsamında; Türkiye $(7,30)$, Avrupa $(16,91)$ ve Dünya $(7,46)$ ortalamalarının altında kalmıştır. ${ }^{14}$ Bununla birlikte, canlı donör sayısı açısından Türkiye $(52,01)$ Dünyada ilk sırada yer almıştır. ${ }^{15}$

Türkiye'de, organ bağışı ve nakli ile ilgili bilgi ve tutumlar hakkında farklı gruplar üzerinde yapılmış olan çok sayıda çalışma bulunmaktadır. Bu çalışmalarda, organ bağışı sayılarının yetersiz olmasının sebepleri olarak; başta bilgi eksikliği olmak üzere dini açıdan duyulan kaygı, korku, yaşarken yeterince tıbbi bakım alamama kaygısı, vücut bütünlüğünün bozulmasını istememe, ebeveynlerin bilgi eksikliği ve ölüm sonrasında sağlık personelinin aile ile zayıf iletişimi tespit edilmiştir. ${ }^{16-23} \mathrm{Bu}$ alanda yapılan çalışmalar, organ bağışı ve nakli hakkındaki bilgi eksikliklerinin ve bilinçlendirme kapsamında yapılacakların tespit edilmesine önemli katkılar sağlamaktadır.

Bu çalışmanın amacı; bir yükseköğretim kurumundaki genel kolluk kuvveti öğrencilerinin organ bağışı ve nakli hakkındaki bilgi düzeylerini tespit etmek, öğrencilerin tanımlayıcı özelliklerindeki farklıııkların bilgi düzeyleri üzerine etkilerini incelemektir. 


\section{GEREÇ VE YÖNTEM}

Kesitsel tanımlayıcı tipteki bu araştırmanın evrenini, Ankara'da bulunan Jandarma ve Sahil Güvenlik Akademisi'nde eğitim ve öğrenim gören 4767 öğrenci oluşturmaktadır. Örneklem büyüklüğünün hesabında; varsayılan frekans örneklem büyüklüğünü maksimize edecek şekilde $\% 50$ olarak alınmış olup, \%99 güven seviyesinde ve \%5 örnekleme hatası kapsamında, basit tesadüfi örnekleme yöntemi ile 583 öğrenciye ulaşılması hedeflenmiştir. Farklı akademik birimlerde bulunan öğrencilerin cinsiyetlerine göre örneklemde yeterince temsil edilmesini sağlamak için orantısal tabakalı örnekleme yöntemi kullanılmıştır. Araştırmaya ait veriler 2-9 Aralık 2019 tarihleri arasında toplanmıştır.

Veri toplama aracı olarak iki bölümden oluşan bir anket uygulanmıştır. Anketin birinci bölümünde; Öztürk Emiral ve ark. tarafından geliştirilerek, geçerliliği ve güvenirliliği ispat edilmiş 17 maddeden oluşan "OrganDoku Bağışı ve Nakli Bilgi Ölçeği” kullanılmıştır. Ölçek, 5 maddelik "Donör Özellikleri” başlıklı birinci boyut ile 12 maddelik "Organ Bağışı ve Nakline iliş̧in Yasal, Etik ve Tıbbi İ̧̧lemler" başlıklı ikinci boyuttan oluşmaktadır. Ölçekte 9 olumlu ve 8 olumsuz önerme bulunmakta olup, katılımcıların her bir önermeye "Doğru", "Yanlış" ve "Bilmiyorum" cevaplarından birisini vermesi istenmiştir. Ölçekteki her bir maddeye verilen doğru cevap 1 puan ile puanlandırılmıs olup, alınabilecek puan aralıkları; ölçeğin geneli için 0-17, birinci boyutu için 0-5 ve ikinci boyutu için 0-12 olacak şekilde düzenlenmiştir. ${ }^{24}$ Ölçekten alınan puan arttıkça bilgi düzeyinin de arttığı kabul edilmiştir. Anketin ikinci bölümünde ise katılımcıların tanımlayıcı özelliklerine ait 7 soru yer almaktadır.

Verilerin analizinde istatistik yazııım paket programı kullanılmış olup; tanımlayıcı tablolarda frekans, yüzde, ortalama ve standart sapma değerleri belirtilmiştir. Verilerin normal dağılım göstermemesi ve homojen olmaması nedeniyle istatistiki analizlerde parametrik olmayan testler kullanılmış olup, öğrencilerin tanımlayıcı özelliklerindeki farklılıkların bilgi düzeyleri üzerine etkileri Mann-Whitney $U$ ve Kruskal-Wallis testleriyle analiz edilmiştir. İki kategorik değişken arasındaki ilişkinin analizinde Ki-Kare ve Fisher'in Kesin testleri kullanılmıştır. Analiz sonuçlarında, $p<0,05$ istatistiki olarak anlamlı kabul edilmiştir.

Bu çalışma Atııı Üniversitesi İnsan Araştırmaları Etik Kurulu tarafından onaylanmış (Tarih: 16.10.2019, Sayı:5863) olup, araştırma öncesinde araştırmanın yürütüldüğü kurumdan idari izin alınmıştır. "Gönüllü Katılım Formu”nu imzalayarak araştırmaya katılmayı kabul eden öğrencilere anket uygulaması yapılmıştır. “Organ-Doku Bağışı ve Nakli Bilgi Ölçeği”nin bu çalışmada kullanılabilmesi için ölçeğin geçerlilik ve güvenirlilik çalışmasını yapan sorumlu araştırmacıdan izin alınmıştır.

\section{BULGULAR}

Çalışmada örnekleme yöntemi ile tespit edilen 583 öğrenciye ulaşılmıştır. Büyük çoğunluğu erkek $(\% 91,4)$ ve bekâr $(\% 81,6)$ olan katılımcıların yaşları 18 ile 37 yıl arasında değişmekte olup, yaş ortalaması 25,32 44,13 yıldır. Katılımcıların öğrenim durumları çoğunlukla önlisans $(\% 35,0)$ ve lisans $(\% 48,0)$ mezunu seviyesindedir. Öğrencilerin büyük bir çoğunluğunun $(\% 98,1)$ organ nakli yapılmış olan bir aile üyesi bulunmamaktadır. Katılımcılar arasında organ bağışı yapmış olanların oranı $(\% 2,1)$ oldukça düşük iken, gelecekte organ bağışı yapmayı düşünenlerin oranı $(\% 33,8)$ daha yüksek bulunmuştur. Organ bağışı yaptığını belirten katılımcıların tamamı aile üyelerinde organ nakli öyküsü bulunmayan erkek öğrencilerden oluşmaktadır. Katılımcıların tanımlayıcı özelliklerine ait veriler Tablo 1'de bulunmaktadır.

Öğrencilerin “Organ-Doku Bağışı ve Nakli Bilgi Ölçeği”nde bulunan önermelere verdikleri cevapların puan ortalamaları; birinci boyut için 3,59 $\pm 0,86$ olup, ikinci boyut için $9,13 \pm 2,08$ ve ölçeğin geneli için $12,73 \pm 2,49$ olarak bulunmuştur. Katılımcıların; ölçeğin 1., 5., 15. maddelerindeki önermelere yüksek düzeylerde (\%90,7$97,4)$ ve 2., 4., 10. maddelerindeki önermelere düşük düzeylerde $(\% 27,6-56,8)$ doğru cevap verdikleri görülmüştür. Katılımcıların ölçekteki önermelere verdikleri cevaplar Tablo 2'de görülmektedir. 
Tablo 1. Katılımcıların tanımlayıcı özellikleri $(n=583)$

\begin{tabular}{|c|c|c|}
\hline Tanımlayıcı özellikler & $\mathbf{n}$ & $\%$ \\
\hline \multicolumn{3}{|l|}{ Cinsiyet } \\
\hline Erkek & 533 & 91,4 \\
\hline Kadın & 50 & 8,6 \\
\hline \multicolumn{3}{|l|}{ Medeni durum } \\
\hline Bekâr & 476 & 81,6 \\
\hline Evli & 107 & 18,4 \\
\hline \multicolumn{3}{|l|}{ Öğrenim durumu } \\
\hline Lisans öğrencisi & 79 & 13,6 \\
\hline Önlisans mezunu & 204 & 35,0 \\
\hline Lisans mezunu & 280 & 48,0 \\
\hline Yüksek lisans mezunu & 20 & 3,4 \\
\hline \multicolumn{3}{|l|}{ Yaş aralığı } \\
\hline $18-22$ & 136 & 23,3 \\
\hline $23-27$ & 340 & 58,3 \\
\hline $28-32$ & 45 & 7,7 \\
\hline $33-37$ & 62 & 10,7 \\
\hline \multicolumn{3}{|c|}{ Aile üyelerinizden organ nakli yapılan var mı? } \\
\hline Evet & 11 & 1,9 \\
\hline Hayır & 572 & 98,1 \\
\hline \multicolumn{3}{|l|}{ Organ bağışı yaptınız mı? } \\
\hline Evet & 12 & 2,1 \\
\hline Hayır & 571 & 97,9 \\
\hline \multicolumn{3}{|c|}{ Gelecekte organ bağışı yapmayı düşünür müsünüz? ( $n=571)$} \\
\hline Evet & 197 & 34,5 \\
\hline Hayır & 104 & 18,2 \\
\hline Kararsızım & 270 & 47,3 \\
\hline
\end{tabular}

Katılımcıların cinsiyetlerine göre ölçeğin geneli için aldıkları puan ortalamalarında farklılıklar bulunmuş olup, kadın öğrencilerin puan ortalamasının erkek öğrencilerinkinden yüksek olduğu görülmüştür $(p<0,05)$. Katılımcıların diğer tanımlayıcı özelliklerine göre ölçek puanı ortalamalarında anlamlı bir farklıık bulunamamıştır. Öğrencilerin tanımlayıcı özelliklerine göre ölçek puanı ortalamaları ve bu puanların karşılaştırıımasına ilişkin sonuçlar Tablo 3'te bulunmaktadır. Gelecekte organ bağışı yapmayı düşündüğünü belirten katılımcılar analiz edildiğinde; kadınların erkeklerden, bekârların evlilerden, düşük yaş gruplarındakilerin 33-37 yaş grubundakilerden anlamlı bir şekilde daha yüksek oranlarda organ bağışı yapmayı düşündükleri görülmüştür $(p<0,05)$. 
Tablo 2. Katılımcıların organ-doku bağışı ve nakli bilgi ölçeğindeki önermelere verdikleri cevaplar ( $n=583)$

\begin{tabular}{|c|c|c|c|}
\hline \multirow{2}{*}{ Önermeler } & \multicolumn{2}{|l|}{ Doğru } & Bilmiyorum \\
\hline & $\mathrm{n}$ & $\%$ & n $\quad \%$ \\
\hline
\end{tabular}

\section{Donör özellikleri}

1. Organ bağışı; "Bir kişinin hayatta iken serbest iradesi ile tıbben yaşamı sona erdikten sonra doku ve organlarının başka hastaların tedavisi için kullanılmasına izin vermesi ve bunu belgelendirmesidir" diye tanımlanabilir.

2. Organ bağışı yapabilmek için yaş sınırı vardır. ${ }^{*}$

3. Kişi hayatta ve sağlıklı iken bazı organlarını (böbrek, karaciğerin bir kısmı vb.) bağışlayabilir.

4. Yüksek tansiyon ve şeker gibi kronik hastalıklar böbrek nakline neden olabilecek hastalıklardandır.

5. Beyin fonksiyonlarının geri dönülmez bir şekilde kaybolduğu ve solunum cihazına bağlı olmadan yaşamanın mümkün olmadığı duruma "beyin ölümü" denir.

\begin{tabular}{|c|c|c|c|c|c|}
\hline 568 & 97,4 & 8 & 1,4 & 7 & 1,2 \\
\hline 302 & 51,8 & 161 & 27,6 & 120 & 20,6 \\
\hline 518 & 88,9 & 41 & 7,0 & 24 & 4,1 \\
\hline 322 & 55,2 & 104 & 17,9 & 157 & 26,9 \\
\hline 529 & 90,7 & 28 & 4,8 & 26 & 4,5 \\
\hline 67 & 11,5 & 432 & 74,1 & 84 & 14,4 \\
\hline 336 & 57,6 & 159 & 27,3 & 88 & 15,1 \\
\hline 94 & 16,1 & 425 & 72,9 & 64 & 11,0 \\
\hline 33 & 5,7 & 524 & 89,9 & 26 & 4,4 \\
\hline 104 & 17,8 & 331 & 56,8 & 148 & 25,4 \\
\hline 488 & 83,7 & 17 & 2,9 & 78 & 13,4 \\
\hline 370 & 63,5 & 134 & 23,0 & 79 & 13,5 \\
\hline 39 & 6,7 & 494 & 84,7 & 50 & 8,6 \\
\hline 453 & 77,7 & 58 & 9,9 & 72 & 12,4 \\
\hline 6 & 1,0 & 564 & 96,8 & 13 & 2,2 \\
\hline 485 & 83,2 & 27 & 4,6 & 71 & 12,2 \\
\hline 94 & 16,1 & 422 & 72,4 & 67 & 11,5 \\
\hline
\end{tabular}

Organ bağışı ve nakline ilişkin yasal, etik ve tıbbi işlemler

6. Beyin ölümü gerçekleşen kişinin tekrar iyileşme ihtimali vardır.*

7. Beyin ölümü ile koma/bitkisel yaşam farklı şeylerdir.

8. Her ölüm olayından sonra kişinin organları nakil için alınabilir.*

9. Bir kişiden alınan organlar herkese nakledilebilir. ${ }^{*}$

10. Tüm nakil işlemlerinde alıcı-verici arasında kan grubu uyumu olması yeterlidir.*

11. Ülkemizde böbrek, karaciğer gibi organların dışında kalp-akciğer, deri, kemik iliği, ince bağırsak gibi organların da nakli yapılmaktadır.

12. Hayatta iken organ bağışı yapan ve hastanede beyin ölümü gerçekleşen kişinin organlarının alınıp-alınmaması konusunda son karar ailesine aittir.

13. Hayatta iken organ bağışı yapmayan ve hastanede beyin ölümü gerçekleşen kişinin organlarının alınıp-alınmaması konusunda son karar hekime aittir.*

14. Hayatta iken organ bağışında bulunan ve organı alınan kişi (böbrek, karaciğerin bir kısmı vb.) hayatının geri kalanını sağlıklı geçirebilir.

15. Organ nakli sadece akrabalar arasında yapılır.*

16. Kişiler alkol, uyuşturucu madde vb. gibi bağımlılık yapan maddeler kullanarak organ nakline neden olabilecek hastalık oluşturabilirler.

17. Organ nakli sadece tıbbi ölümü gerçekleşmiş insanlardan (kadavra) yapılabilir.*

*Olumsuz önermedir.

\section{TARTIŞMA}

Araştırma sonuçlarına göre, katılımcı öğrencilerin organ bağışı ve nakli hakkındaki bilgileri orta düzeyde bulunmuştur. Aynı ölçeğin kullanıldığı diğer çalışmalarla karşılaştırıldığında, bu çalışmada tespit edilen organ bağışı ve nakline ilişkin puan ortalamalarının; Öztürk Emiral ve ark.nın 2014-2015 yıllarında bir eğitim ve araştırma hastanesinde görevli 540 sağlık dışı personel üzerinde yaptığı çalışmada bulunan sonuçlardan daha yüksek olduğu, Soylar ve ark.nın 2018 yılında bir üniversitede 578 öğrenci üzerinde yaptığı çalışmada tespit edilen sonuçlardan daha düşük olduğu görülmüştür. Öztürk Emiral ve ark.nın çalışmasında katılımcıların 1. boyuta ilişkin bilgi seviyeleri 2. boyuta ilişkin bilgi seviyelerinden daha yüksek bulunmuşken, Soylar ve ark.nın çalışmasında ve bu çalışmada ise 2. boyuta ilişkin bilgi seviyelerinin daha yüksek olduğu görülmüştür. ${ }^{24,25}$ Öztürk Emiral ve ark.nın çalışmasında eğitim seviyesi yüksek, ekonomik durumu iyi, aile üyelerinde organ nakli öyküsü bulunan ve organ bağışı yapmaya istekli olanlarda ölçek puanı 
ortalamalarının anlamlı bir şekilde yüksek olduğu görülmüşken; bu çalışmada sadece kadın öğrencilerin ölçek puanı ortalamasının erkek öğrencilerinkinden anlamlı bir şekilde yüksek olduğu tespit edilmiştir. Bu çalışmada; 33-37 yaş grubundakiler, aile üyelerinde organ nakli öyküsü olanlar, organ bağışı yapanlar ve gelecekte organ bağışı yapmayı düşündüğünü belirten katılımcıların ölçek puanı ortalamalarının yüksek olduğu görülse de bu tanımlayıcı özelliklere göre ortalama puanlarında anlamlı bir farklılık bulunamamıştır.

Tablo 3. Katılımcıların tanımlayıcı özelliklerine göre ölçek puanı ortalamalarının karşılaştırılması ( $n=583)$

\begin{tabular}{|c|c|c|c|c|}
\hline Tanımlayıcı özellikler & $\mathrm{n}$ & $\%$ & Puan (Ort $\pm S S)^{*}$ & $\mathrm{p}^{* *}$ \\
\hline \multicolumn{5}{|l|}{ Cinsiyet } \\
\hline Erkek & 533 & 91,4 & $12,62 \pm 2,51$ & \multirow{2}{*}{$0,000^{\mathrm{a}}$} \\
\hline Kadın & 50 & 8,6 & $13,84 \pm 2,04$ & \\
\hline \multicolumn{5}{|l|}{ Medeni durum } \\
\hline Bekâr & 476 & 81,6 & $12,71 \pm 2,42$ & \multirow{2}{*}{0,377} \\
\hline Evli & 107 & 18,4 & $12,79 \pm 2,79$ & \\
\hline \multicolumn{5}{|l|}{ Öğrenim durumu } \\
\hline Lisans öğrencisi & 79 & 13,6 & $12,86 \pm 2,39$ & \multirow{4}{*}{0,078} \\
\hline Önlisans mezunu & 204 & 35,0 & $12,35 \pm 2,64$ & \\
\hline Lisans mezunu & 280 & 48,0 & $12,96 \pm 2,35$ & \\
\hline Yüksek lisans mezunu & 20 & 3,4 & $12,70 \pm 2,93$ & \\
\hline \multicolumn{5}{|l|}{ Yaş aralı̆̆ı } \\
\hline $18-22$ & 136 & 23,3 & $12,69 \pm 2,35$ & \multirow{4}{*}{0,631} \\
\hline $23-27$ & 340 & 58,3 & $12,68 \pm 2,52$ & \\
\hline $28-32$ & 45 & 7,7 & $12,71 \pm 2,86$ & \\
\hline $33-37$ & 62 & 10,7 & $13,09 \pm 2,41$ & \\
\hline \multicolumn{5}{|c|}{ Aile üyelerinizden organ nakli yapılan var mı? } \\
\hline Evet & 11 & 1,9 & $14,09 \pm 1,70$ & \multirow{2}{*}{0,064} \\
\hline Hayır & 572 & 98,1 & $12,70 \pm 2,50$ & \\
\hline \multicolumn{5}{|l|}{ Organ bağışı yaptınız mı? } \\
\hline Evet & 12 & 2,1 & $13,58 \pm 2,02$ & \multirow{2}{*}{0,229} \\
\hline Hayır & 571 & 97,9 & $12,71 \pm 2,50$ & \\
\hline \multicolumn{5}{|c|}{ Gelecekte organ bağışı yapmayı düşünür müsünüz? (n=571) } \\
\hline Evet & 197 & 34,5 & $13,06 \pm 2,16$ & \multirow{3}{*}{0,106} \\
\hline Hayır & 104 & 18,2 & $12,50 \pm 2,64$ & \\
\hline Kararsızım & 270 & 47,3 & $12,53 \pm 2,65$ & \\
\hline
\end{tabular}

*Ort: Ortalama; SS: Standart sapma; Ölçekteki her bir maddeye verilen doğru cevap 1 puan ile puanlandırılmış olup, ölçeğin geneli için puan aralığı 0-17 olacak şekilde düzenlenmiştir.

${ }^{* *}$ Mann-Whitney $U$ ve Kruskal-Wallis testleri uygulanmıştır $\left({ }^{a} p<0,05\right)$.

Türkiye'de organ bağışı ve nakli ile ilgili bilgi ve tutumlar hakkında farklı gruplar üzerinde yapılmış olan çalışmalarda; katılımcıların organ bağışı oranı \%0,5-3,3 arasında, organ bağışı yapmaya istekli olanların oranı $\% 22,5-58,2$ arasında bulunmuştur. ${ }^{16,21,24-27}$ Bu çalışmada da katıımcıların \%2,1'inin organ bağışı yaptığı ve \%33,8'inin gelecekte organ bağışı yapmayı düşündüğü tespit edilmiş olup, bu sonuçların diğer çalışmalarda elde edilen sonuçlarla uyumlu olduğu değerlendirilmiştir. Özbek Yazıcı ve ark.nın 2013-2014 yıllarında bir üniversitede 352 öğrenci üzerinde yaptığı çalışmada, kız öğrencilerin anlamlı bir şekilde erkeklerden daha fazla oranda organlarını bağışlamayı düşündükleri saptanmıştır. ${ }^{23}$ Bu çalışmada da kadınların erkeklerden 
anlamlı bir şekilde daha yüksek oranda organ bağışı yapmayı düşündükleri görülmüştür. Ayrıca; bekârların evlilerden, düşük yaş gruplarındakilerin de 33-37 yaş grubundakilerden anlamlı bir şekilde daha yüksek oranda organlarını bağışlamayı düşündükleri tespit edilmiştir.

Katıımcıların büyük çoğunluğunun $(\% 90,7-97,4)$, organ bağışı ve beyin ölümü tanımlarını bildiği ve organ naklinin sadece akrabalar arasında yapılmadığının farkında oldukları görülmüştür. Bununla birlikte, öğrencilerin önemli bir bölümünün (\%27,6-56,8), organ bağışında yaş sınırı olmadığını ve kronik hastalıkların böbrek nakline neden olabileceğini bilmedikleri ve tüm nakil işlemlerinde alıcı-verici arasında kan grubu uyumu olması gerekmediğinin farkında olmadıkları görülmüştür. Yapılan çalışmalarda, organ bağışı kararını olumsuz yönde etkileyen faktörlerin en başında bilgi eksikliğinin geldiği ortaya konmuştur. ${ }^{17-19,21,23,27-30} \mathrm{Bu}$ çalışmada, gelecekte organ bağışı yapmayı düşünmeyenlerin bilgi düzeylerinin görece düşük olduğu bulunmuş olsa da katılımcıların bu tanımlayıcı özelliğine göre ortalama puanlarında anlamlı bir farklılık bulunamamıştır.

Dini inançların da organ bağışı kararını etkileyen önemli bir faktör olduğu yapılan çalışmalar ile ortaya konmuştur. ${ }^{26,28,31-34}$ Hiçbir din organ bağışını veya organ almayı yasaklamaz, canlı veya ölü bağışçılardan nakillere karşı değildir. ${ }^{35}$ Dini gelenekler resmi olarak organ bağışı ve naklini yasaklamasa da bu konuda, dini grupların mensupları tarafından kendi anlayışlarına göre bir tutum benimsenmektedir. ${ }^{36} 1980$ yılında Diyanet iş̧leri Başkanlığı, organ bağışını bir insanın insana yapabileceği en büyük yardım olarak tanımlamıştır. ${ }^{37}$ Bu çalışmada, katııımcılara dini inançları sorulmamış olsa da Türkiye'de toplumun büyük bir bölümü Müslüman olup, İslamiyet'te organ bağışı iyilik ve merhamet eylemi olarak kabul edilir. ${ }^{38,39}$

Tutumun gözlenebilen bir davranış olmadığı, davranışa hazırlayıcı bir eylem olduğu ifade edilebilir. Herhangi bir tutum nesnesi hakkında edinilen bilgilerin davranışa dönüştürülme aşamasında, bireyin kendi duygusal tepkisi ile birlikte dışarıdan gelen tepkiler de etkili olmaktadır. ${ }^{40} \mathrm{Bu}$ kapsamda, kişilerin organ bağışı ve nakli hakkındaki bilgi düzeylerinin organ bağışına yönelik tutumlarını etkileyeceği söylenebilir. Bununla birlikte tutum değişikliklerinin her zaman için davranışlara yansıması da beklenmemelidir.

$\mathrm{Bu}$ araştırma genç erişkin populasyon üzerinde yapılmış olup, sonuçları bu gruba özgü bilgileri yansıtmaktadır. Çalışmanın bu sınırlıı̆ından dolayı sonuçların diğer gruplara genelleştirilemeyeceği düşünülmektedir. Bununla birlikte; organ bağışı ve nakli ile ilgili bilgi düzeyleri konusundaki çalışmaların genellikle sağlık personeli ve öğrencileri ile hasta grupları üzerinde yapıldığı düşünüldügünde, farklı bir populasyon olan genel kolluk kuvveti öğrencileri üzerinde yapılan bu çalışmanın literatüre ayrıca bir katkı sunacağı değerlendirilmektedir.

\section{SONUÇ}

Araştırma sonuçları çalışmanın yapıldığı yükseköğretim kurumundaki öğrencilerin organ bağışı ve nakli hakkındaki bilgi düzeylerini ortaya koymakta olup, bu kapsamda yapılması gereken bilinçlendirme faaliyetlerinin belirlenmesine katkı sunacağı değerlendirilmektedir. Katılımcıların bilgilerinin yeterli düzeylerde olmadığı görülmüş olup, öğrencilerin organ bağışı ve nakli hakkında özellikle düşük düzeyde farkındalık tespit edilen konularda bilgilendirilmeleri önerilmektedir. Organ bağışı ve nakli konusunda bilinçlendirilmiş öğrencilerin, mezuniyetleri sonrasında farkı bölgelerde görev yapacak olmaları dikkate alındığında; organ bağışına yönelik toplumsal farkındalığın arttırılmasına katkı sunabilecekleri düşünülmektedir.

Genç erişkin populasyon üzerinde yapılan bu araştırmaya ait bulguların, benzer grupların organ bağışı ve nakli konusundaki bilgi düzeyleri hakkında fikir verebileceği ve yapılacak bilinçlendirme çalışmalarının belirlenmesine katkı sunabileceği değerlendirilmektedir. Bu kapsamda; organ bağışı ve nakli konusundaki 
bilinçlendirme çalışmalarında, üniversitelerde ve askeri okullarda bulunan genç erişkin gruplar hedef kitle olarak seçilmelidir.

\section{BiLGi}

Araştırmayı destekleyen kurum/kuruluş bulunmamaktadır.

\section{KAYNAKLAR}

1. World Health Organization. WHO task force on donation and transplantation of human organs and tissues. https://www.who.int/transplantation/donation/taskforce-transplantation/en/ (Erişim tarihi: 20.11.2019)

2. Akış $M$, ve ark. Süleyman Demirel Üniversitesi personelinin organ-doku bağışı ve nakli hakkındaki bilgi ve tutumları. SDÜ Tıp Fakültesi Dergisi 2008;15(4):28-33.

3. Delmonico FL. Interview with Dr Joseph Murray. Am J Transplant 2002;2(9):803-6.

4. Toledo-Pereyra LH, Sutherland DE. Richard Carlton Lillehei: Transplant and shock surgical pioneer. J Invest Surg 2011;24(2):4952.

5. Starzl TE, et al. Orthotopic homotransplantation of the human liver. Ann Surg 1968;168(3):392-415.

6. Barnard CN. The operation. A human cardiac transplant: An interim report of a successful operation performed at Groote Schuur Hospital, Cape Town. S Afr Med J 1967;41(48):1271-4.

7. Ceylan i. Türklerde cerrahinin gelişimi. Ankara: Türk Cerrahi Derneği Yayınları; 2012:143.

8. Haberal M. Development of transplantation in Turkey. Transplant Proc 2001;33(7-8):3027-9.

9. Önal G. Türkiye'de ilk pankreas nakli: En büyük sorun organ bağışı. Cumhuriyet Gazetesi 16 Aralık 1989; Bilim Teknik eki (145):1.

10. Toronto Lung Transplant Group. Unilateral lung transplantation for pulmonary fibrosis. N Engl J Med 1986;314(18):1140-5.

11. Süreyyapaşa Akciğer Transplantasyonu Çalışma Grubu. Silikozis tanısıyla yapılan tek taraflı akciğer nakli: Türkiye'deki ilk başarılı akciğer nakli olgusu. Türk Göğüs Kalp Damar Cerrahisi Dergisi 2011;19(3):455-62.

12. Council of Europe. Shortage of organs, tissues and cells for transplantation in Europe.

https://www.coe.int/en/web/human-rights-channel/organ-donation (Erişim tarihi: 23.11.2019)

13. Council of Europe and Organización Nacional de Trasplantes. Newsletter transplant-International figures on donation and transplantation 2018. Technical Report Vol. 24. Strasbourg: Council of Europe; 2019.

14. Global Observatory on Donation and Transplantation. http://www.transplant-observatory.org/summary/ (Erişim tarihi: 29.11.2019)

15. International Registry in Organ Donation and Transplantation.

http://www.irodat.org/img/database/pdf/IRODaT\%20Newsletter\%202019-March.pdf (Erişim tarihi: 29.11.2019)

16. Gürler H, Topal Hançer A. Bir aile sağlığı merkezine başvuran bireylerin organ bağışı konusundaki tutumları. Turkiye Klinikleri J Med Ethics 2020;28(1):90-8.

17. İbrahimoğlu Ö, Urhan S. Knowledge, attitudes, and behaviors of healthcare workers about organ donation. Sağlık Akademisyenleri Dergisi 2019;6(2):142-9.

18. Dumanlı A, ve ark. Afyon Kocatepe Üniversitesi Tıp Fakültesi öğrencilerinin organ veya doku nakli ve organ bağışı hakkında bilgi tutum ve davranışları. Kocatepe Tıp Dergisi 2019; 20(2): 58-62.

19. Yılmaz M, Demirağ S. Tıp fakültesi öğrencilerinin organ bağışı ve nakli ile ilgili bilgi, düşünce ve tutumlarına tıp eğitiminin etkisi. Ankara Medical Journal 2019;19(2):316-24.

20. Şantaş G, Şantaş F. Türkiye'de organ bağışının mevcut durumu ve organ bağışında stratejik iletişimin önemi. SDÜ Sağlık Bilimleri Enstitüsü Dergisi 2018;9(2):163-8.

21. Bostancıoğlu D, Saraçoğlu GV, Öztürk M. Yüksekokul öğrencilerinin organ bağışı konusundaki bilgi düzeylerinin ve tutumlarının araştırılması. Genel Tıp Dergisi 2017;27(4):140-51.

22. Topbaş E, Bingöl G. Türkiye'de kadavra donörden gerçekleştirilen organ nakline etki eden faktörler. Nefroloji Hemşireliği Dergisi 2016;11(2):77-88.

23. Özbek Yazıcı S, ve ark. Hemşirelik öğrencilerinin organ nakli ve bağışı konusunda bilgi ve düşüncelerinin belirlenmesi. Mehmet Akif Ersoy University Journal of Health Sciences Institute 2015;3(2):66-76.

24. Ozturk Emiral G, et al. Development of a reliable and valid organ tissue donation and transplantation knowledge scale. Transplant Proc 2017;49(2):260-6.

25. Soylar P, Kadıoglu BU. Theology and nursing students' knowledge of organ donation and transplantation. Transplant Proc 2018;50(10):2961-5.

26. Demir Doğan $M$, ve ark. Üniversite öğrencilerinin organ bağışına bakış açısı ve bilgi düzeyleri. Sağlık Bilimleri ve Meslekleri Dergisi 2016;3(2):99-105.

27. Yakıt E, Şen MA. Sağlık Hizmetleri Meslek Yüksekokulu öğrencilerinin organ bağış hakkındaki görüş ve davranışlarının belirlenmesi. Journal of Social And Humanities Sciences Research 2017;4(11):623-30. 
28. Kocaay AF, et al. Brain death and organ donation: Knowledge, awareness, and attitudes of medical, law, divinity, nursing, and communication students. Transplant Proc 2015;47(5):1244-8.

29. Akkas M, et al. Changing attitudes of medical students regarding organ donation from a university medical school in Turkey. Medical Science Monitor 2018;24:6918-24.

30. Katsari V, et al. Giving your last gift: A study of the knowledge, attitude and information of Greek students regarding organ donation. Annals of Transplantation 2015;20:373-80.

31. Sahin $\mathrm{H}$, Abbasoglu O. Attitudes of medical students from different countries about organ donation. Experimental and Clinical Transplantation [Epub ahead of print]. Doi: 10.6002/ect.2014.0228

32. Ali NF, et al. Knowledge and ethical perception regarding organ donation among medical students. BMC Medical Ethics 2013;14:38.

33. Symvoulakis EK, et al. Organ donation knowledge and attitudes among health science students in Greece: Emerging interprofessional needs. International Journal of Medical Sciences 2014;11(6):634-40.

34. Naçar M, et al. Knowledge attıtudes and behaviors about organ donatıon among fırst- and sixth-class medıcal students: A study from Turkey. Transplant Proc 2015;47(6):1553-9.

35. Bruzzone P. Religious aspects of organ transplantation. Transplant Proc 2008;40(4):1064-7.

36. Özbolat A. "Organlarımla dirilmek istiyorum."- Organ bağışının dini-toplumsal arkaplanı. Çukurova Üniversitesi İlahiyat Fakültesi Dergisi 2017;17(1):61-87.

37. T.C. Diyanet İşleri Başkanlığı, Din İşleri Yüksek Kurulunun 06.03.1980 tarihli ve 396 sayılı kararı. http://www.organnakli.hacettepe.edu.tr/bagis.shtml (Erişim tarihi: 10.12.2019)

38. Golmakani MM, Niknam MH, Hedayat KM. Transplantation ethics from the Islamic point of view. Medical Science Monitor 2005;11(4):RA105-9.

39. Albar M. Organ transplantation: A Sunni Islamic perspective. Saudi Journal of Kidney Diseases and Transplantation 2012;23(4):817-22.

40. Kağıtçıbaşı Ç. İnsan ve insanlar. İstanbul: Evrim Basım Yayım Dağıtım; 1988:84. 